\title{
Основные подходы к созданию перспективных сортов яровой мягкой пшеницы для Западной Сибири
}

Белан И.А. ${ }^{1 *}$, к.с-х.н., зав. лабораторией; Россеева Л.П. ${ }^{1}$, к.с-х.н., в.н.с.; Блохина Н.П. ${ }^{1}$, с.н.с.; Немченко В.В. ${ }^{2}$, д.с-х.н.; Абакумов С.Н. ${ }^{3}$, зам. директора; Трубачеева Н.В. ${ }^{4}$, к.б.н, н.с.; Першина Л.А. ${ }^{4}$, д.б.н., г.н.с.

${ }^{l}$ ФГБНУ «Омский АНЦ», Омск, Россия;

${ }^{2}$ ООО НЦ «Кургансемена», Курган, Россия;

${ }^{3}$ ФГУП «Опеновское», Тюменская обл., Россия;

${ }^{4}$ ИЦиГ СО РАН, Новосибирск, Россия.

*e-mail: belan_skg@mail.ru

Рассмотрены результаты создания перспективных сортов яровой мягкой пшениџы для Западной Сибири с использованием ряда подходов. Показана эффективность использования в гибридизаиии коммерческих сортов и перспективных линий местной селекции и созданных в других регионах; интрогрессивных линий, носителей генов устойчивости к листостебельным патогенам; аллоплазматических ДГ-линий, сочетающих ичитоплазму культурного ячменя $H$. vulgare и генов устойчивости к биотическим факторам.

Ключевые слова: пшеница, аллоплазматические ДГ-линии, сорта, урожайность, устойчивость.

\section{Main approaches for creating promising varieties of spring bread wheat for Western Siberia}

Belan Igor Aleksandrovich ${ }^{1}$, Rosseeva Ludmila Petrovna ${ }^{l}$, Blokhina, Natalya Pavlovna ${ }^{l}$, Nemchenko Vladimir Vasilyevich ${ }^{2}$, Abakumov Sergey Nikolaevich ${ }^{3}$, Trubacheeva Natalya Victorovna ${ }^{4}$, Pershina Lidiya Aleksandrovna ${ }^{4}$

${ }^{1}$ FGBSI "Omsk ASC", Omsk, Russia;

${ }^{2} S C$ "Kurgansemena", Kurgan, Russia;

${ }^{3}$ FSUE "Openovskoe", Tyumen region, Russia;

${ }^{4}$ IC\&G, SB RAS, Novosibirsk, Russia.

The results of creating promising varieties of springbread wheat for Western Siberia using a number of approaches are considered. The effectiveness of involvement in hybridization when creating source material for breeding commercial varieties and promising lines created in other regions was shown; introgression lines, carriers of genes for resistance to leaf-stem pathogens; alloplasmic DH lines combining the cytoplasm of cultured barley H.vulgare and genes of resistance to biotic factors.

Key words: wheat, alloplasmic DH lines, varieties, productivity, stability. 
Яровая мягкая пшеница - одна из наиболее ценных продовольственных культур, возделываемых на значительных площадях в Западной Сибири. Основные направления селекции на протяжении последних 40 лет были связаны с увеличением урожайности, адаптивности и качества продукции. За эти годы в Госреестр России и Казахстана было включено 29 сортов лаборатории селекции яровой мягкой пшеницы ФГБНУ «Омский АНЦ», в настоящее время допущено к возделыванию 24 сорта лаборатории.

В последние годы, начиная с 2015 по 2019 гг., в Западной Сибири отмечены контрастные погодные условия и эпифитотии листостебельных патогенов. В связи с этим к сортам, обладающим устойчивостью к неблагоприятным биотическим и абиотическим факторам и характеризующимся повышенной урожайностью, проявляется большой интерес, поскольку возделывание таких сортов приводит к уменьшению потерь урожая. Один из подходов для реализации селекционных программ заключается в создании рекомбинантных генотипов, используемых в качестве исходных форм, на основе привлечения в скрещивания линий, выделенных из коммерческих и перспективных сортов, полученных в других регионах. В результате были получены такие сорта как Омская 12, Омская 18, Омская 28, Омская 32, Омская 36 и др.

Другой подход основан на использовании в гибридизации при создании исходного материала интрогрессивных линий, носителей генов устойчивости к листостебельным патогенам. Источниками таких генов в наших работах являются рожь посевная $S$. cereale и дикорастущие сородичи мягкой пшеницы (T. durum, T. dicoccum, T. dicoccoides, Ag. elongatum, Ag. intermedium, T. timopheevii). В процессе создания и проработки селекционного материала проводятся лабораторные и полевые оценки на устойчивость к патогенам бурой и стеблевой ржавчины $[1,2]$, а также контроль за наличием генов устойчивости к грибным патогенам [3].

Кроме того, в качестве исходного материала используются аллоплазматические ДГ-линии мягкой пшеницы, сочетающие цитоплазму культурного ячменя H.vulgare и комплексы генов устойчивости к грибным патогенам. Так, из гибридной популяции, полученной в результате гибридизации (аллоплазматическая линия ДГ-17 // Laj 3302 / Дружина) были выделены перспективные линии яровой мягкой пшеницы, имеющие пшенично-ржаную транслокацию $1 \mathrm{RS} .1 \mathrm{BL}$ (носитель комплекса генов устойчивости Lr26/Sr31/Yr9/Pm8). Три из этих линий Л-311(4), Л-311(5) и Л-311(6) были переданы на ГСИ. По итогам государственного сортоиспытания в 2016 г. среднеспелый сорт Сигма (№ патента РФ 7950) включен в Госреестр РФ по 10 региону. В 2019 г. этот сорт возделывался в Омской области на площади 31024,5 га. В 2019 г. среднепоздний сорт Уралосибирская 2 (№ патента РФ 9568) включен в Госреестр РФ по 9 и 10 регионам. На момент включения сорта в Госреестр РФ площади составили в Омской области 381 га, в Курганской - 500 га. Патент на среднеранний сорт Ишимская 11 (№ патента РФ 
10854) получен в 2020 г. Кроме того, последние два сорта проходят государственное сортоиспытание в Республике Казахстан. Эти сорта характеризуются высокой устойчивостью к стеблевой ржавчине $(И У<0,35)$ и средней к бурой ржавчине (ИУ $0,36 \div 0,65)$. Результаты GISH анализа подтвердили наличие у этих сортов пшенично-ржаной транслокации $1 \mathrm{RS} .1 \mathrm{BL}$, а метод молекулярного анализа показал наличие генов $\operatorname{Lr} 26$ и $\operatorname{Sr} 31$.

В течение пяти лет (2015-2019 гг.) сорта Сигма и Уралосибирская 2 изучались в селекционных питомниках лаборатории селекции яровой мягкой пшеницы ФГБНУ «Омский АНЦ». Стандартом для среднеспелого сорта Сигма служил сорт Дуэт, для среднепозднего сорта Уралосибирская 2 - сорт Серебристая, а для среднераннего сорта Ишимская 11 - сорт Омская 36.

Особенностью этих лет являлось массовое развитие листостебельных заболеваний. Метеорологические условия в годы исследования были контрастны и в полной мере отображали климатические особенности лесостепной зоны Омской области. Благоприятными условиями для возделывания яровой мягкой пшеницы были 2017, 2018 и 2019 гг., два года - 2015 и 2016 были неблагоприятными. В течение вегетационного периода в 2015 г. температурный режим соответствовал среднемноголетней и характеризовался избытком осадков в мае, июне и августе месяцах и недобором в июле, что привело к затягиванию периода колошение восковая спелость, а в 2016 г. температура была выше среднемноголетней, июнь и июль характеризовались избытком, а август - недобором осадков, что привело к короткому периоду колошение - восковая спелость. Такие условия были неблагоприятны как для реализации генетического потенциала сортов по урожайности, так и развитию листостебельных патогенов, однако массовому развитию этих заболеваний способствовало наличие росы на листьях и период ее продолжительности [4].

В среднем в неблагоприятные годы (2015 и 2016 гг.) по урожайности среднеспелый сорт Сигма (2,19 т/га) превзошел на 0,37 т/га сорт стандарт Дуэт (1,82 т/га). Среднепоздний сорт Уралосибирская 2 (2,16 т/га) превзошел сорт стандарт Серебристая (1,51 т/га) на 0,65 т/га, а среднеранний Ишимская $11(4,62$ т/га) - на 0,52 т/га сорт стандарт Омская 36 (4,10 т/га). В благоприятные годы потери урожайности восприимчивых к листостебельным патогенам стандартов были более значительны. Так, урожайность сорта стандарта Дуэт составила 3,45 т/га, что на 0,81 т/га ниже, чем у сорта Сигма (4,26т/га), у сорта стандарта Серебристая $(3,44$ т/га) на 1,05 т/га меньше, чем у сорта Уралосибирская 2 (4,49т/га). Среднеранний сорт Ишимская 11(4,79 т/га) в благоприятные годы превзошел по урожайности на 0,95 т/га сорт Омская 36 (3,84 т/га).

Достоинством сортов Сигма, Уралосибирская 2 и Ишимская 11 являются высокие показатели качества зерна, независимо от условий выращива- 
ния. В неблагоприятные годы масса 1000 зерен у стандартов Дуэт и Серебристая не превышала 26 г., а у сортов Сигма и Уралосибирская 2 значительно выше - 34,7г. и 32,4 г., соответственно. В благоприятные годы разница в массе 1000 зерен была более существенной и равнялась 12,1 г. между сортом Сигма и стандартом Дуэт, а между сортом Уралосибирская 2 и стандартом Серебристая - 11,6 г. По содержанию белка в зерне новые сорта превосходили стандарты Дуэт и Серебристая в неблагоприятные годы на 1,3 и 4,05 $\%$, а в благоприятные $-1,76$ и 2,37 \%, соответственно. Преимуществом новых сортов также является содержание сырой клейковины в зерне, которое превышает 30 \%, независимо от условий выращивания, что соответствует 12 классу. Показатели качества зерна сорта Ишимская 11 по данным ФГУП «Опеновское» за 2012-2014 гг. следующие: натура зерна достигала 741 г/л, масса 1000 зерен - 38,1 г, стекловидность - $51 \%$, содержание сырой клейковины - 30,1 \%, белка - 15,27 \%, сила муки - 314 е.а., валориметр - 81 ед. вал., объем хлеба - $1010 \mathrm{~cm}^{3}$, общая хлебопекарная оценка - 4,3 балла.

Таким образом, благодаря повышенной урожайности в сочетании с высоким уровнем устойчивости к стеблевой ржавчине и хорошими хлебопекарными свойствами новые сорта Сигма, Уралосибирская 2 и Ишимская 11 могут успешно конкурировать с сортами аналогичной группы спелости.

Благодарности: Отдельные разделы работы выполнены при поддержке РФФИ (проект № 20-016-00196).

\section{Список литературы}

1. Белан И.А. Создание сортов мягкой пшеницы устойчивых к грибным заболеваниям для условий Западной Сибири и Урала / Белан И.А., Россеева Л.П., Мешкова Л.В., Блохина Н.П., Першина Л.А., Трубачеева Н.В. // Вестник Алтайского государственного аграрного университета, 2017. - № 1 (147). - С. 5-14.

2. Россеева Л.П. Селекция на устойчивость к стеблевой ржавчине яровой мягкой пшеницы в Западной Сибири / Россеева Л.П., Белан И.А., Мешкова Л.В., Блохина Н.П., Ложникова Л.Ф., Осадчая Т.С., Трубачеева Н.В., Першина Л.А. // Вестник Алтайского государственного аграрного университета, 2017. - № 7 (153). - С. 5-12.

3. Першина Л.А. Аллоплазматические рекомбинантные линии (H. vulgare)T. Aestivum с транслокацией 1RS.1BL: исходные генотипы для создания сортов мягкой пшеницы / Першина Л.А., Л.И. Белова, Трубачеева Н.В., Осадчая Т.С., Шумный В.К., Белан И.А., Россеева Л.П., Немченко В.В., Абакумов С.Н. // Вавиловский журнал генетики и селекции, 2018. - Т. 22. - № 5. - С. 544-552.

4. Першина Л.А. Изучение особенностей андрогенеза в культуре пыльников сортов и перспективной формы яровой мягкой пшеницы западносибирской селекции, различающихся наличием или отсутствием пшенично-чужеродных транслокаций / Першина Л.А., Осадчая Т.С., Бадаева Е.Д., Белан И.А., Россеева Л.П. // Вавиловский журнал генетики и селекции, 2013. - Т. 17. - № 1.- С.40-49. 